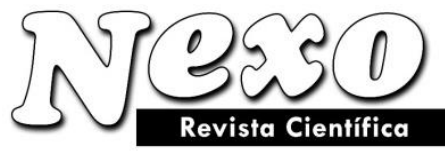

Universidad Nacional de Ingeniería COPYRIGHT @ (UNI). TODOS LOS DERECHOS RESERVADOS http://revistas.uni.edu.ni/index.php/Nexo https://doi.org/10.5377/nexo.v33i01.10049

\title{
COMPOSITION AND AGE OF MONACITE FRAGMENTS FROM SUPERIOR JURASSIC TERRIGENOUS SEDIMENTS OF BAZHENOV FORMATION FOUNDATION (MULTAN AREA IN WEST SIBERIA)
}

\section{COMPOSICIÓN Y EDAD DE FRAGMENTOS DE MONACITA DE SEDIMENTOS TERRÍGENOS JURÁSICOS SUPERIORES EN LA BASE DE FORMACIÓN DE BAZHENOV (ÁREA MULTAN, SIBERIA OCCIDENTAL)}

\author{
Yuriy V. Erokhin*, Kirill S. Ivanov, Vera V. Khiller \\ Institute of Geology and Geochemistry, Ural Branch of the Russian Academy of Sciences, Ekaterinburg, \\ Russia \\ *erokhin-yu@yandex.ru
}

(recibido/received: 15-diciembre-2019; aceptado/accepted: 04-febrero-2020)

\begin{abstract}
Bazhenov Formation is regarded as the main oil-bearing stratum mothering nearly all the fields of the Western Siberia Oil-Gas-bearing Megabasin. Presently, it is one of the most studied formations of Siberia and, probably, Eurasia as a whole. While there is an enormous amount of studies devoted to the Bazhenov Formation, there are no detailed mineralogical studies at the modern hardware level. The age and sources of the terrigenous materials of the formation have not been studied as well. We have explored the detrital monazite from the upper-Jurassic terrigenous sediments of the Multan Area at the foundation of the Bazhenov Formation in the central part of Western Siberia, Surgut District. All the detrital rare earth phosphate is of the cerium kind being a monazite- $(\mathrm{Ce})$. The mineral is rather dissimilar in respect of its chemical properties, especially, the content of thorium. Some fragments have been subjected to superposed secondary changes. The detrital monazite is rounded to various degrees which is indicative of the various distances from the rare earth phosphate orebody washout. As per the chemical data, most of the monazite has been washed out from the medium and basic rocks (probably subalkaline or alkaline) as well as the sialic rocks (granitoids and associated veins). According to the chemical dating, most of the monazite fragments have been washed out of the very ancient Proterozoic formations and lower-Proterozoic rocks. Terrigenous materials derives probably from the rock assemblages of the eastern and south-eastern fringes of the Western Siberian megabasin such as the Proterozoic Yenisei Ridge or Lower-Proterozoic blocks of the Altay and Sayan Faulting.
\end{abstract}

Keywords: Detrital monazite; Chemical dating; Aleurolite; Multan area; Surgut district; West Siberian megabasin. 


\section{RESUMEN}

La Formación Bazhenov es considerada como el principal estrato petrolero que es madre de casi todos los campos de la megacuenca petrolera de Siberia occidental. Por ahora es una de las formaciones más estudiadas de Siberia y, quizás, de Eurasia. Aúnque hay una cantidad enorme de estudios dedicados a la formación Bazhenov, no hay estudios mineralógicos detallados en el nivel moderno de hardware. Tampoco se han estudiado la edad y los fuentes de los materiales terrígenos de la formación. Hemos explorado la monacita detrítica de los sedimentos terrígenos jurásicos superiores del Área Multana en la base de la formación Bazhenov en el centro de Siberia Occidental, Distrito de Surgut. Todo el fosfato detrítico de la tierra rara pertenece al tipo cerio y se refiere como monacita-(Ce). El mineral es bastante disimilar en cuanto a sus propiedades químicas, especialmente a su contenido de torio. Unos fragmentos han estado sometidos a cambios superpuestos secundarios. Se redondea la monacita detrítica a grados diferentes lo cual es un indicador de varias distancias de la inundación del yacimiento de fosfato de la tierra rara. Según los datos químicos, la mayoría de la monacita ha sido lavado de las rocas mediana y básicas (probablemente, alcalinas y subalcalinas) así como de las rocas siálicas (granitoidas y capas asociadas). Según datación química, la mayoría de los pedazos monazíticos han sido lavado de las formaciones Proterozóicas muy viejas y rocas Proterozóicas tempranas. Los materiales terrígenos se derivan probablemente de los conjuntos rocosos de los márgenes sudoriental y oriental de la megacuenca de Siberia Occidental, tales como la Cresta Proterozóica de Yenisei o los conjuntos de rocas Proterozóicas Tempranas de la Falla de Altay y Sayan.

Palabras clave: Monacita detrítica; Datación química; Aleurolita; Área de multan; Distrito de Surgut; Megacuenca de Siberia occidental

\section{INTRODUCTIÓN}

The Western Siberian Bazhenov Formation is represented mostly by the Later-Jurassic absolutely nonmetamorphosed bituminous argillites and silicites. The thickness is usually small, about 20 meters. Nevertheless, presently Bazhenov Formation is one of the most studied ones in Eurasia (Gurari, 1981; Dorofeyeva et al., 1983; Kontorovich et al., 1998; Predtechenskaya et al., 2006; Zanin et al., 2016 and many others). All the mentioned and may other works consider various aspect of composition, distribution and origin of the formation's rocks. There are several main reasons for that:

Firstly, Bazhenov Formation is considered as the main oil-bearing formation having mothered all the fields of the West Siberia Oil-Gas-bearing Megabasin. A vast variety of literature has been devoted to that matter, which is not to be considered in this article. We have to note only, that nothing is exactly clear in this case (which is normal for geology as a whole): there is an alternative concept of the deep origin of the West Siberian oil (Ivanov et al., 2008; Timurziyev et al., 2014). Thus, A.A. Nezhdanov et al. (2012) note, that the sediments and migration hypothesis does not explain the regularity of the hydrocarbon deposits and changes in their content. The discrepancy between location of hydrocarbons and changes in the organic matter content of the main oil-bearing formation of the Western Siberia (Bazhenovskaya) are noted. Should the oil in the basin be generated by Bazhenov Formation, then its bituminousness (organic carbon content) should have decreased sharply under the oil fields and in the "feeding" troughs including, for example, the Latitudinal near-Ob. Nevertheless, it does not happen, and the bituminousness changes smoothly over Bazhenov Formation in conformance with the sedimentology models ignoring the presence of the fields to include such giants as Samotlor, Fyodorovskoye, Ust-Balyk, East Surgut, Povkhovskoye etc.

Secondly, the interest for the shale oil and related matters has grown in the world. Interestingly, according to the western estimates, Russia is the first in respect of its reserves far ahead of all. Nearly all of those "reserves" (not really reserves, but resources!) are related to the West Siberia. Bazhenov Formation which is known to be spread over the vast territory of about 1 million square kilometers giving rise to the enormous

Nexo Revista Científica / Vol. 33, No. 01, pp. 84-93 / Junio 2020 


\section{Yuriy V. Erokhin et al.}

resource estimates varying by ten times or more reaching the unreal 300 billion tons. This matter is out of scope of our consideration. We should note only the absence of a cost-effective Bazhenov Formation tight oil extraction technology with the only exception of the experimental extraction at the Middle-Nazym field (Kokorev et al., 2014) carried out by RITEK OJSC (a subsidiary of LUKoil) by thermal and gas heat transfer about 4 years ago when the oil price was about $\$ 100$. On the whole, the Bazhenov Formation (as well as all other oil shale formations of Russia) is a "thing as it is" which may be developed only in future subject to some conditions (Ivanov et al., 2016 and others), including a comprehensive study of the Bazhenov Formation rocks composition and properties, since shale oil extraction requires massive hydraulic fracturing. At the same time, despite the great number of studies, there are none exploring the rocks of Bazhenov Formation at the modern hardware level. Moreover, there are no studies of the age and sources of the terrigenous material of the formation, that we will attempt to correct in this work by our exploration of the detrital monazite of the upper-Jurassic terrigenous sediments of the Multan Area in West Siberia. Detrital monazites have been studied by ourselves earlier (Ivanov et al., 2015 and others). They are quite reliable for the reconstruction of sources of the ablation.

\section{ANALYTICAL METHODS}

While studying the accessory mineralization of the upper-Jurassic deposits we revealed fractional monazites, their aged determined by microprobe analysis. Lately, chemical dating has been revived by the development of the microprobe analysis and its computer applications. This method applied to monazites, uraninite, zircon, xenotime, titanite and others is known as CHIME (Chemical Th-U-total Pb Isochron Method). Its growing popularity is due to its availability with electron probe microanalyzers and scanning electronic microscopes.

The theoretical basis of the CHIME methodology is substantiated in the works (Suzuki et al., 1991; Montel et al., 1996; Williams et al., 1999; Jercinovic, Williams, 2005; Suzuki, Kato, 2008 and others); with satisfactory consistency of chemical dating and isotope research pointed out by many of them (Dahl et al., 2005; Suzuki, Kato, 2008; Ivanov et al., 2010, Khiller et al., 2015 and others). It is worth noting, that the authors of the cited works do not confront CHIME with isotopic geochronology considering it rather as an auxiliary or sometimes the only possible method of assessment of age of a mineral or rock. The method is based on the three principal theses: 1) all lead in a mineral is radiogenic, 2) lead concentration reaches the levels detectable by electron probe microanalyzer in 100 million years, 3 ) the system of $\mathrm{U}, \mathrm{Th}, \mathrm{Pb}$ is "closed" which means, that diffusion (losses) may be neglected. Chemical dating is based on the equation of parent isotope decay and radiation accumulation of radiogenic lead (Montel et al., 1996 and others). Of the U-Th$\mathrm{Pb}$-containing minerals, monazite (waterless phosphate of a rare-earth element) is used for chemical isochron dating most often. As an accessory mineral, it is found in all sialic and alkaline magmatic rocks as well as in metamorphic and metasomatic rocks. As a stable mineral, it can accumulate in sedimentary rocks. Monazite has a high isomorphic content in the lanthanides as well as phosphorus position. Admixtures are typical and numerous, up to 20-25 elements including REE, Th, U, Y, Zr, Ca, Si, S etc. Sometimes, ThO2 and UO2 are enough for lead to accumulate in the monazites.

Chemical composition of the upper-Jurassic monazites of the Multan Area was explored with CAMECA SX 100 electron probe microanalyzer built by the Institute of Geology and Geochemistry of the Ural Branch of the Russian Academy of Science. Analyzes were conducted at high strength 250-270 nA and accelerating voltage of $15 \mathrm{kV}$. The time for analysis in one point was 8-10 minutes. Age calculations were made according to (Montel et al., 1996) with using its own software development (Khiller, 2010).

\section{GEOGRAPHIC AND GEOLOGICAL POSITION OF THE MULTAN AREA}

Multan Area is situated in the central part of the Western Siberian Megabasin and southern part of Surgut District, Khanty-Mansy Autonomous Region (see Picture 1), $90 \mathrm{~km}$ to the south-south-east of Pyt-Yakh and $10 \mathrm{~km}$ to the east of Multanovy settlement. Geologically (tectonically) the area is in the central part of Yugansk Megadepression in the Aikuruss Ledge (more exactly, in its northern extension). Geologic structure

Nexo Revista Científica / Vol. 33, No. 01, pp. 84-93 / Junio 2020 
of Yugansk Megadepression's pre-Jurassic basement was considered by ourselves recently (Ivanov et al., 2016). Yugansk Zone consists mostly of Paleozoic igneous and sedimentary rocks as well as of terrigenous and carbonate structures laid over by two Perm and early-Triassic graben rifts. The smaller of them is Taurovsky, named after Taurova settlement with the deep well Taurovskaya R-503 drilled to the west of the settlement to penetrate the rift's volcanic rocks. The more eastern Kaimysovsky graben rift connects with Koltogorsk one in the north of the explored area. Kaimysovsky graben rift is named after Kaimysovy settlement, of which to the north and north-east the graben rift's volcanic rocks are opened with wells Guslinskaya R-430 and Western-Chistinnaya R-501. According to the sharp change in the rocks lithology and the nature of the physical fields (especially, the geodynamic model matrices), all the submeridian contacts between the structural and formational zones of the explored area are tectonic ones.

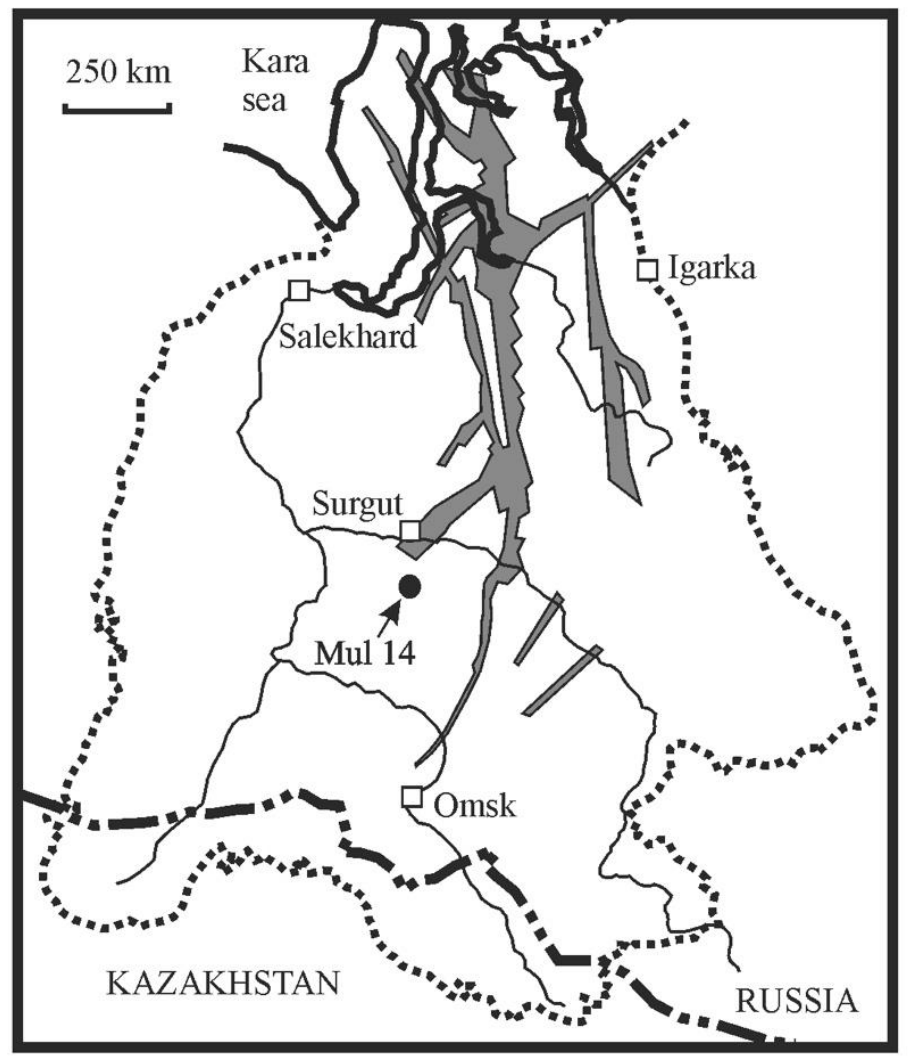

Figure 1. Western Siberian Platform with Urengoy-Koltogorsk Triassic rift (see (Surkov et. al., 1997)) and well Multanovskaya № 14.

A relatively detailed section of Jurassic and Cretaceous sediments of the Multan Area is provided in (Galinskiy et al., 2017) where bituminous argillites and silicites are shown at the depth of $2780-2880$ meters in wells № 12 and 14. To explore the upper-Jurassic sedimentary rocks in well № 14, we took bituminous samples from the depths of 2853.3 and 2870 meters as well as laminated aleurolite from the lower stratum of Bazhenov Formation 2881.5 meters) with the purpose of chemical dating of the detrital monazite. The sampled aleurolite is of the same age as Bazhenov Formation sedimentary rocks, i.e. upperJurassic.

\section{FINDINGS AND DISCUSSION}




\section{Yuriy V. Erokhin et al.}

The aleurolite from well № 14 contains a large number of small grains of the detrital monazite. Phosphate grains vary in form from short prisms to round and xenomorphic shapes having usually no more than 50 micrometers in length (see Picture 2). We have studied five different grains of the detrital monazite.

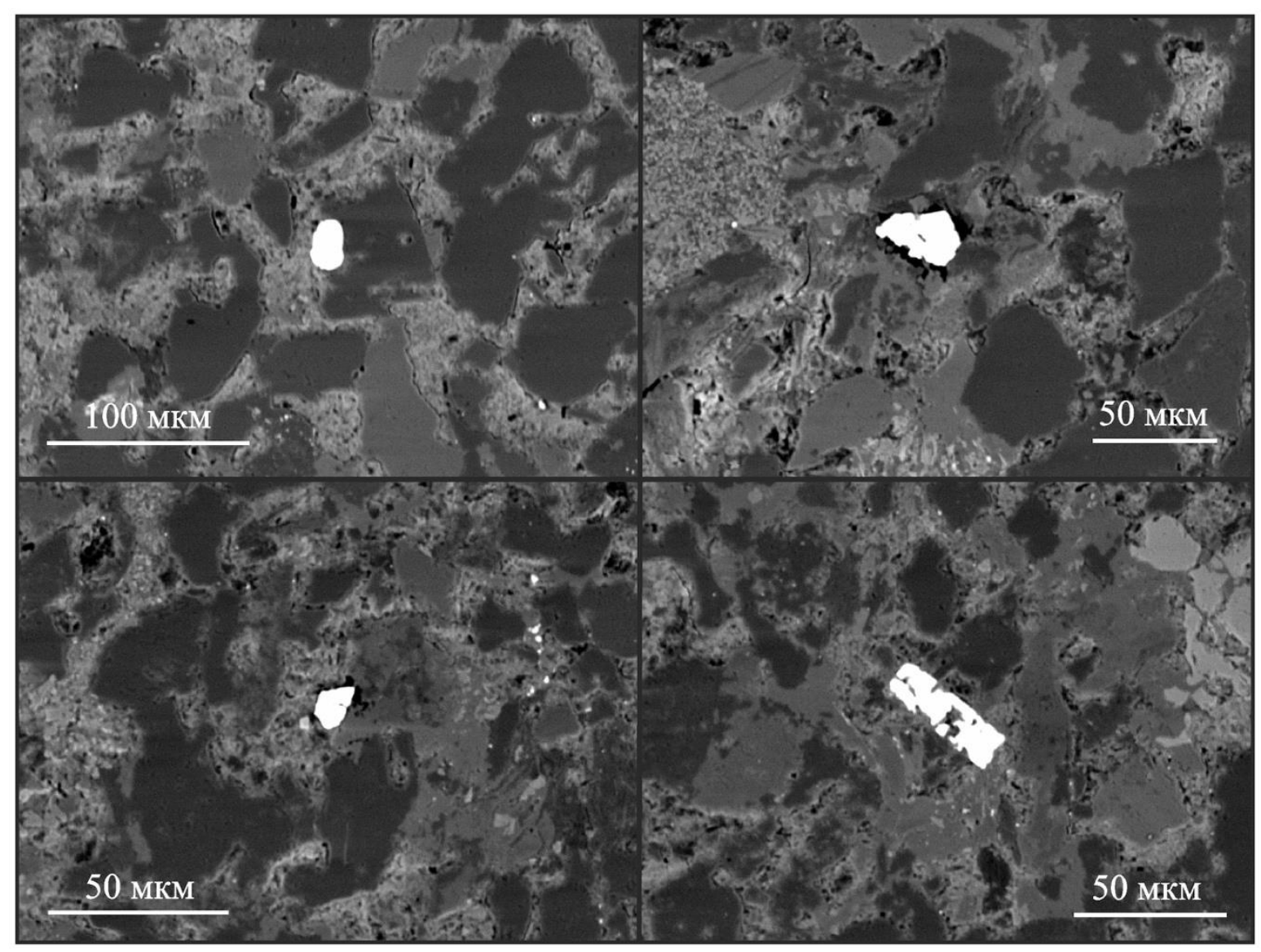

Figure 2. Monazite Grains in Aleurolite Matrix - BSE View - CAMECA SX 100 microanalyser - Sample Mul. 14/2881.5 m.

The chemical composition of monazites in this siltstone varies considerably from one grain to another (see Table) which reveals the variety of sources of the substances diffused and deposed while forming the sediment. All fragments are of the cerium kind and relate to monazite-(Ce) though differing in respect of their thorium content varying from almost zero to 9 mass \%. From other admixtures are observed also rare earths, silicium, uranium, yttrium and calcium. Some grains have totals close to $100 \%$ which reveals the absence of secondary changes in the phosphate matrix. Other grains had undergone later changes revealed by the low sum of analyzed oxides and sharp loss of lead.

Table 1. Chemical Composition of Monazite (mass \%) from Sample Mul. 14/2881.5 m

\begin{tabular}{|c|c|c|c|c|c|c|c|c|c|c|c|}
\hline \multirow{2}{*}{ No. } & 1 & 2 & 3 & 4 & 5 & 6 & 7 & 8 & 9 & 10 & 11 \\
\hline & \multicolumn{4}{|c|}{1 grain } & \multicolumn{3}{|c|}{2 grain } & \multicolumn{4}{|c|}{3 grain } \\
\hline $\mathrm{P}_{2} \mathrm{O}_{5}$ & 29.02 & 29.06 & 29.06 & 29.13 & 28.87 & 28.78 & 23.26 & 26.94 & 26.97 & 27.21 & 27.10 \\
\hline $\mathrm{ThO}_{2}$ & 3.31 & 2.90 & 2.52 & 2.58 & 1.49 & 3.10 & 1.83 & 9.16 & 8.40 & 7.91 & 7.54 \\
\hline $\mathrm{UO}_{2}$ & 0.11 & 0.12 & 0.07 & 0.08 & - & - & 0.04 & 0.09 & 0.08 & 0.09 & 0.06 \\
\hline $\mathrm{SiO}_{2}$ & 0.26 & 0.24 & 0.19 & 0.23 & 0.42 & 0.65 & 1.61 & 1.71 & 1.73 & 1.64 & 1.66 \\
\hline $\mathrm{Ce}_{2} \mathrm{O}_{3}$ & 29.36 & 29.56 & 29.87 & 29.68 & 32.87 & 31.94 & 28.20 & 30.48 & 30.29 & 30.91 & 31.07 \\
\hline $\mathrm{La}_{2} \mathrm{O}_{3}$ & 12.88 & 13.10 & 13.11 & 12.91 & 19.30 & 18.91 & 15.47 & 17.96 & 17.62 & 17.68 & 17.39 \\
\hline
\end{tabular}

Nexo Revista Científica / Vol. 33, No. 01, pp. 84-93 / Junio 2020 
Farnoush Naghsh et al.

\begin{tabular}{|l|l|l|l|l|l|l|l|l|l|l|l|}
\hline $\mathrm{Nd}_{2} \mathrm{O}_{3}$ & 12.20 & 12.40 & 12.41 & 12.69 & 10.05 & 9.77 & 7.97 & 9.06 & 9.27 & 9.15 & 9.07 \\
\hline $\mathrm{Pr}_{2} \mathrm{O}_{3}$ & 3.32 & 3.23 & 3.43 & 3.32 & 2.94 & 2.76 & 2.44 & 2.62 & 2.69 & 2.90 & 2.70 \\
\hline $\mathrm{Sm}_{2} \mathrm{O}_{3}$ & 2.26 & 2.18 & 2.27 & 2.27 & 0.76 & 0.70 & 0.61 & 0.66 & 0.67 & 0.67 & 0.64 \\
\hline $\mathrm{Gd}_{2} \mathrm{O}_{3}$ & 1.71 & 1.70 & 1.70 & 1.70 & 0.35 & 0.42 & 0.38 & 0.18 & 0.28 & 0.31 & 0.30 \\
\hline $\mathrm{Dy}_{2} \mathrm{O}_{3}$ & 0.71 & 0.70 & 0.67 & 0.74 & - & - & 0.02 & - & 0.01 & - & - \\
\hline $\mathrm{Y}_{2} \mathrm{O}_{3}$ & 2.81 & 2.70 & 2.47 & 2.59 & 0.12 & 0.10 & 0.11 & 0.08 & 0.12 & 0.14 & 0.16 \\
\hline $\mathrm{PbO}$ & 0.07 & 0.08 & 0.06 & 0.06 & 0.01 & 0.02 & - & 0.66 & 0.62 & 0.61 & 0.58 \\
\hline $\mathrm{CaO}$ & 0.58 & 0.53 & 0.49 & 0.52 & 0.76 & 0.80 & 0.78 & 0.89 & 0.73 & 0.77 & 0.98 \\
\hline Total & 98.61 & 98.48 & 98.33 & 98.49 & 97.94 & 97.94 & 82.72 & 100.5 & 99.46 & 100.0 & 99.22 \\
\hline $\begin{array}{l}\mathrm{Age}, \\
\mathrm{Ma}\end{array}$ & 460 & 558 & 498 & 492 & - & - & - & 1601 & 1618 & 1701 & 1697 \\
\hline
\end{tabular}

Note: Hereinafter - CAMECA SX 100 electron probe microanalyzer built by the Institute of Geology and Geochemistry of the Ural Branch of the Russian Academy of Science; analyst by V.V. Khiller.

On the whole, the chemical composition of monazites allows to determine the rocks having served a basis for the Multan Area siltstones. The main petrological criterion here is the content of thorium increasing from the medium and basic rocks to sialic rocks. Therefore, it follows from the table that rare-earth phosphates were blurred both from medium and basic rocks (probably subalkaline or alkaline) and from sialic rocks (granitoids and associated veins - pegmatites, etc.).

Table 1. (cont.). Chemical Composition of Monazite (mass \%) from Sample Mul. 14/2881.5 m

\begin{tabular}{|c|c|c|c|c|c|c|}
\hline \multirow{2}{*}{ No. } & 12 & 13 & 14 & 15 & 16 & 17 \\
\hline & \multicolumn{6}{|c|}{4 grain } \\
\hline $\mathrm{P} 2 \mathrm{O} 5$ & 29.35 & 29.23 & 29.42 & 29.66 & 29.43 & 29.29 \\
\hline ThO2 & 3.82 & 5.25 & 3.36 & 3.87 & 4.07 & 5.27 \\
\hline $\mathrm{UO} 2$ & 0.27 & 0.41 & 0.22 & 0.35 & 0.35 & 0.43 \\
\hline $\mathrm{SiO} 2$ & 0.34 & 0.51 & 1.37 & 0.77 & 0.36 & 0.50 \\
\hline $\mathrm{Ce} 2 \mathrm{O} 3$ & 28.66 & 28.08 & 29.07 & 29.77 & 28.14 & 27.31 \\
\hline La2O3 & 12.19 & 13.52 & 13.21 & 11.57 & 12.27 & 11.44 \\
\hline $\mathrm{Nd} 2 \mathrm{O} 3$ & 14.10 & 12.36 & 13.18 & 13.25 & 13.89 & 13.85 \\
\hline Pr2O3 & 3.35 & 3.14 & 3.23 & 2.97 & 3.25 & 3.48 \\
\hline $\mathrm{Sm} 2 \mathrm{O} 3$ & 2.43 & 2.15 & 2.04 & 2.09 & 2.24 & 2.37 \\
\hline Gd2O3 & 1.89 & 1.88 & 1.68 & 1.55 & 1.97 & 2.03 \\
\hline Dy2O3 & 0.70 & 0.78 & 0.59 & 0.56 & 0.78 & 0.82 \\
\hline $\mathrm{Y} 2 \mathrm{O} 3$ & 1.99 & 2.33 & 1.78 & 1.55 & 2.17 & 2.31 \\
\hline $\mathrm{PbO}$ & 0.10 & 0.10 & - & 0.10 & 0.11 & 0.14 \\
\hline $\mathrm{CaO}$ & 0.68 & 0.84 & 0.59 & 1.11 & 0.79 & 0.89 \\
\hline Total & 99.87 & 100.57 & 99.73 & 99.17 & 99.84 & 100.14 \\
\hline Age, $\mathrm{Ma}$ & 515 & 352 & - & 477 & 484 & 492 \\
\hline
\end{tabular}

The chemical dating of the detrital monazite shows (see Picture 3), that Multan siltstones have the substrate of very ancient Proterozoic rocks (1,6 - 1,7 billion years) as well as of relatively ancient ones from lowerPaleozoic strata dating back to the lower-Ordovician and Cambrian periods ( $460-560$ million years). One sample, which may be ignored, dated back to the Carboniferous period (352 million years). It means, that the source of monazites was, probably, on the eastern margin of the Wester Siberian Megabasin where the earliest rocks are (Yenisei Ridge etc.) as well as in its south-eastern margin where lower-Paleozoic blocks of Altay and Sayan Faulting are situated. Some of the detrital monazites may have their source of erosion locally, because the granitoids located in the pre-Jurassic section here (in the centre of Western Siberia as 
Yuriy V. Erokhin et al.

well as to the east and north-east of Khanty-Mansiysk) are late-Ordovician and early-Silurian ages (Ivanov et al., 2013).

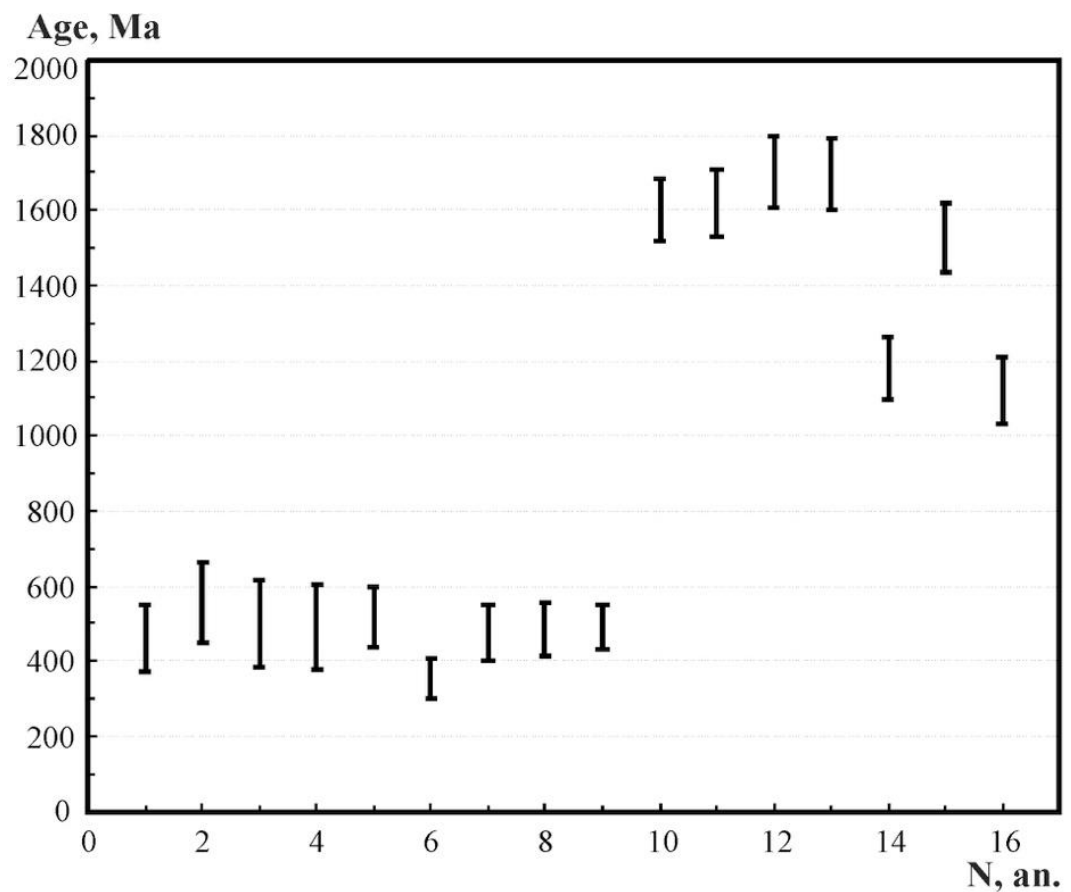

Figure 3. Weighted Average Age of Multan Area Upper-Jurassic Monazites

Our conclusion as to the different sources of demolition of the monazites is in line with (Galinskiy et al., 2017) claiming on the grounds of the lithologic exploration that all the Yugansk Megadepression upperJurassic and lower-Cretaceous sediments were formed by the same source of ablation, meaning the single fluvial sediments system with rivers flowing from east to west. In our opinion, it could erode local as well as distant motherlodes in the south-east and east of Western Siberia.

Table 1 (cont.). Chemical Composition of Monazite (mass \%) from Sample Mul. 14/2881.5 m

\begin{tabular}{|l|l|l|l|l|l|l|l|l|}
\hline \multirow{2}{*}{ No. } & 18 & 19 & 20 & 21 & 22 & 23 & 24 & 25 \\
\cline { 2 - 9 } & 5 grain \\
\hline P2O5 & 28.44 & 28.55 & 28.66 & 28.58 & 28.71 & 28.67 & 28.80 & 28.72 \\
\hline ThO2 & 0.02 & 0.09 & 0.08 & 0.01 & 0.01 & - & 0.01 & 0.02 \\
\hline $\mathrm{UO} 2$ & 0.05 & 0.03 & 0.09 & 0.01 & 0.03 & - & 0.08 & 0.05 \\
\hline $\mathrm{SiO} 2$ & - & 0.01 & 0.02 & 0.03 & 0.03 & - & - & - \\
\hline $\mathrm{Ce} 2 \mathrm{O} 3$ & 30.63 & 31.28 & 31.92 & 31.41 & 31.35 & 32.06 & 31.36 & 31.10 \\
\hline $\mathrm{La} 2 \mathrm{O} 3$ & 13.39 & 13.94 & 14.10 & 14.04 & 14.31 & 14.19 & 13.44 & 13.92 \\
\hline $\mathrm{Nd} 2 \mathrm{O} 3$ & 15.36 & 15.54 & 15.29 & 15.59 & 15.21 & 15.32 & 15.71 & 15.56 \\
\hline Pr2O3 & 3.59 & 3.50 & 3.56 & 3.43 & 3.72 & 3.62 & 3.71 & 3.52 \\
\hline $\mathrm{Sm} 2 \mathrm{O} 3$ & 2.50 & 2.46 & 2.18 & 2.58 & 2.53 & 2.46 & 2.74 & 2.60 \\
\hline $\mathrm{Gd} 2 \mathrm{O} 3$ & 1.66 & 1.33 & 1.16 & 1.56 & 1.48 & 1.27 & 1.65 & 1.51 \\
\hline $\mathrm{Dy} 2 \mathrm{O} 3$ & 0.25 & 0.15 & 0.11 & 0.18 & 0.13 & 0.14 & 0.27 & 0.16 \\
\hline Y2O3 & 0.55 & 0.43 & 0.36 & 0.40 & 0.35 & 0.32 & 0.65 & 0.52 \\
\hline PbO & - & - & - & 0.01 & 0.01 & - & 0.01 & - \\
\hline CaO & 0.62 & 0.42 & 0.52 & 0.54 & 0.52 & 0.47 & 0.37 & 0.57 \\
\hline Total & 97.07 & 97.73 & 98.04 & 98.36 & 98.39 & 98.53 & 98.81 & 98.27 \\
\hline Age, Ma & - & - & - & 1179 & 1529 & - & 1122 & - \\
\hline
\end{tabular}




\section{CONCLUSION}

The study of the detritial monazite from upper-Jurassic sediments of the Multan Area in the south of Surgut District in the central part of the Western Siberian Oil and Gas Megabasin brings the following conclusion: 1. All the detritial rare earth phosphate is of the cerium kind being a monazite-(Ce). The mineral is rather dissimilar in respect of its chemical properties, especially, the content of thorium. Some fragments were subjected to superposed secondary changes which made geochronological calculations impossible.

2. The detritial monazite is rounded to various degrees which is indicative of the various distances from the rare earth phosphate orebody washout. As per the chemical data, most of the monazite has been washed out from the medium and basic rocks (probably subalkaline or alkaline) and from sialic rocks (granitoids and associated veins).

3. According to the chemical dating, most of the detritial monazite have been washed out of the very ancient Proterozoic formations and lower-Proterozoic rocks. Terrigenous materials derives probably from the rock assemblages of the eastern and south-eastern fringes of the Western Siberian megabasin such as the Proterozoic Yenisei Ridge or Lower-Proterozoic blocks of the Altay and Sayan Faulting.

\section{ACKNOWLEDGEMENTS}

This study was carried out with the support of the Russian Science Foundation (No. 16-17-10201).

\section{REFERENCIAS}

Galinskiy K.A., Ikon Ye.V., Illarionova A.M., Borodkin V.N., Reconstruction of Paleogeographic Features of Formation and Sedimentological Studies of the Lower Cretaceous Deposits of the Achimov Stratum in the Central Part of Western Siberia (Yugansk Megadepression) (Vosstanovleniye paleogeograficheskikh osobennostey obrazovaniya i sedimentologicheskikh issledovaniy nizhnemelovykh otlozheniy achimovskoy tolshchiny v tsentralnoy chasti Zapadnoy Sibiri (Yuganskaya megavpadina)) // Geologiya, geofizika $i$ razrabotka neftyanykh i gazovykh mestorozhdeniy, 2017. № 2. P. 14-22.

Gurari F.G., Domaniks and their Oil and Gas Content (Domanikity i ikh neftegazonosnost) // Sovetskaya geologiya. 1981. № 11. P. 3-12.

Dorofeyeva T.V., Krasnov S.G., Lebedev V.A., Petrova G.V., Pozinenko B.V., Oil Collectors of the Bazhenov Formation in Western Siberia (Kollektory nefti bazhenovskoy svity Zapadnoy Sibiri) - L.: Nedra, 1983.

Ivanov K.S., How Much Oil Should be Produced in Russia? (Skolko nefti nado dobyvat Rossii?) // Uralskiy geologicheskiy zhurnal. 2016. № 6. P. 3-10.

Ivanov K.S., Kostrov N.P., Berzin S.V., Vakhrusheva N.V., Erokhin Yu.V., Pogromskaya O.E., Stepanov A.Ye., Tugareva A.V., Zakharov A.V., Yakovleva N.P., A New Geological Map of Pre-Jurassic Basement of the Yugansk and Koltogorsk Zone in Western Siberia (Novaya geologicheskaya karta doyurskogo osnovaniya Yugansko-Koltogorskoy zony Zapadnoy Sibiri) // Puti realizatsii neftegazovogo potentsiala KHMAO. Khanty-Mansiysk: NATS RN im. V.I. Shpilmana, 2016. V. 2. P. 27-39.

Nexo Revista Científica / Vol. 33, No. 01, pp. 84-93 / Junio 2020 


\section{Yuriy V. Erokhin et al.}

Kokorev V.I., Bokserman A.A., Darishchev V.I., Results of Application of the Thermal Impact Technologies to Bazhenov Formation Deposits (Rezultaty realizatsii tekhnologiy termalnogo vozdeystviya na zalezhi bazhenovskoy svity) // Puti realizatsii neftegazovogo potentsiala KHMAO.

Khanty-Mansiysk: NATS RN im. V.I. Shpilmana, 2014. V. 1. P. 59-65.

Kontorovich A.E., Melenevskiy V.N., Zanin Yu.N., Zamiraylova A.G., Kazanenkov V.A., Kazarbin V.V., Makhneva Ye.N., Yamkovaya L.S., Lithology, Organic Biochemistry and Formation Conditions of the Main Types of Natural Resources of the Bazhenov Formation (Litologiya, organicheskaya geokhimiya i usloviya formirovaniya osnovnykh tipov prirodnykh ressursov bazhenovskoy svity) // Geologiya i geofizika. 1998. V. 39. № 11. P. 1477-1491.

Nezhdanov A.A., Ogibenin V.V., Smirnov A.S. Oil and Gas Content of the Western Siberian Basin with Hydrocarbons Depth Origin Positions (Neftegazonosnost Zapadno-Sibirskogo basseyna s pozitsiyami glubinnogo genezisa uglevodorodov) // Materialy Vserossiyskoy konferentsii po glubinnomu genezisu nefti «Sovremennoye sostoyaniye teorii proiskhozhdeniya, metodov prognozirovaniya i tekhnologiy poiskov glubinnoy nefti . M.: TSGE, 2012. P. 22-25.

Predtechenskaya Ye.A., Krol L.A., Gurari F.G., Sapyanik V.V., Perozio G.N., Malyushko L.D., On the Origin of Bazhenov Formation Carbonates in Central and South-Eastern Areas of the Western Siberian Platform (O genezise karbonatov v sostave bazhenovskoy svity tsentralnykh i yugo-vostochnykh rayonov Zapadno-Sibirskoy plity) // Litosfera. 2006. № 4. P. 131-148.

Surkov V.S, Kazakov A.M., Devyatov V.P., Smirnov L.V. Lower- and Medium-Triassic Rift-related Complex of the Western Siberian Basin (Nizhnesrednetriassovy riftogennyy kompleks Zapadno-Cibipckogo bacceyna) // Otechestvennaya geologiya, 1997. № 3. P. 31-37.

Timurziyev A.I., Mantle Foci of Hydrocarbon Generation. Geological and Physical Features and Exploratory Criteria of Mapping. Regularities of Oil and Gas Content of the Subsoil as a Reflection of the Relief of Hydrocarbon Systems in the Earth Crust (Mantiynyye ochagi generatsii uglevodorodov: geologofizicheskiye priznaki i prognozno-poiskovyye kriterii kartirovaniya; zakonomernosti neftegazonosnosti nedr kak otrazheniye razgruzki v zemnoy kore mantiynykh UV-sistem) // Gornyye vedomosti. 2014. № 3 (118). P. 6-30.

Khiller V.V., Composition, Chrystal Chemistry and Evolution of the U-Th-Pb-System of a Number of Geochronometric Minerals According to Experimental Research and Computer Modelling (Sostav, kristallokhimiya, evolyutsiya U-Th-Pb-sistemy ryada mineralov-geokhronometrov po dannym eksperimentalnogo issledovaniya i kompyuternogo modelirovaniya) - Avtoreferat diss. kand. geol.-mineral. nauk. Yekaterinburg: IGG UrO RAN, 2010.

Dahl P.S., Terry M.P., Jercinovic M.J. et al. Electron probe (Ultrachron) microchronometry of metamorphic monazite: Unraveling the timing of polyphase thermotectonism in the Eastern Wyoming Craton (Black Hills, South Dakota) // Amer. Miner. 2005. V. 90. P. 1712-1728.

Jercinovic M.J., Williams M.L. Analytical perils (and progress) in electron microprobe trace element analysis applied to geochronology: Background acquisition, interferences, and beam irradiation effects // Amer. Miner. 2005. V. 90. P. 526-546.

Ivanov K.S., Erokhin Yu.V., Koroteev V.A. First data on Early Paleozoic granitoids in the basement of West Siberia // Doklady Earth Sciences, 2013. Vol. 453. Part 2. P. 1193-1196.

Nexo Revista Científica / Vol. 33, No. 01, pp. 84-93 / Junio 2020 
Ivanov K.S., Khiller V.V., Koroteev V.A., Erokhin Yu.V. Composition and age of detrital monazite from terrigenous rocks: the key to reconstruction of source areas (Northeastern part of the West Siberian megabasin) // Doklady Earth Sciences, 2015. V. 462. Part 2. P. 609-612.

Ivanov K.S., Erokhin Yu.V., Fedorov Yu.N., Khiller V.V., Ponomarev V.S. Isotopic and chemical U-Pb dating of granitoids from the Western Siberian megabasin // Doklady Earth Sciences, 2010. V. 433. Part 2. P. 1070-1073.

Ivanov K., Fedorov Yu., Erokhin Yu., Pogromskaya O., Ronkin Yu., Plotnikova I. Deep origin of oil: Evidences from inorganic geochemistry of oil // 33 International Geological Congress. GEP-13 Abiotic deep origin of hydrocarbons: Myth or reality? Norwey, Oslo, 6-14 August 2008. Abstract 1315951.

Khiller V.V., Reverdatto V.V., Konilov A.N., Viryus A.A., Dokukina K.A., Van K.V., Romanenko I.M. Experience of chemical Th-U-Pb chemical dating of zircon from metasomatic felsic veins of the Gridino area, Belomorian eclogite province // Doklady Earth Sciences, 2015. V. 462. Part 1. P. 494-496.

Montel J.-M., Foret S., Veschambre M., Nicollet C., Provost A. Electron microprobe dating of monazite // Chemical Geology. 1996. V. 131. P. 37-53.

Suzuki K., Adachi M., Tanaka T. Middle Precambrian provenance of Jurassic sandstone in the Mino Terrane, Central Japan: Th-U-total Pb evidence from an electron microprobe monazite study // Sedimentary Geology. 1991. V. 75. P. 141-147.

Suzuki K., Kato T. CHIME dating of monazite, xenotime, zircon and polycrase: Protocol, pitfalls and chemical criterion of possibly discordant age data // Gondwana Research. 2008. V. 14. P. 569-586.

Williams M.L., Jercinovic M.J., Terry M.P. Age mapping and dating of monazite on the electron microprobe: deconvoluting multistage tectonic histories // Geology. 1999. V. 27. № 11. P. 1023-1026.

Zanin Yu.N., Zamirailova A.G., Eder V.G. Uranium, thorium, and potassium in black shales of the Bazhenov Formation of the West Siberian marine basin // Lithology and Mineral Resources. 2016. V. 51. Part 1. P. 7485. 